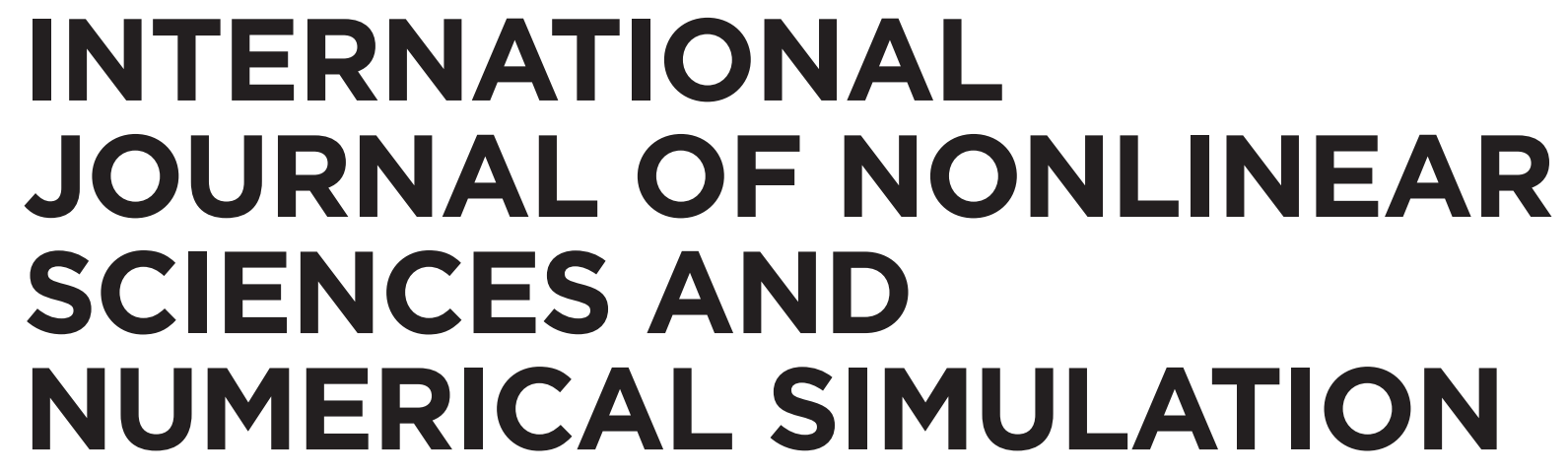

EDITOR-IN-CHIEF

Prof. Björn Birnir,

Santa Barbara, CA

EDITORIAL BOARD

Dieter Armbruster, Tempe, AZ

Hakima Bessaih, Laramie, WY

Tom Chou, Los Angeles, CA

Rainer Grauer, Bochum, Germany

Antonio Marzocchella, Italy

Govindan Rangarajan, Bangalore

Konstantina Trivisa, College Park, MD 
ABSTRACTED/INDEXED IN Chemical Abstracts, Scopus, Current Contents, SciSearch.

The publisher, together with the authors and editors, has taken great pains to ensure that all information presented in this work (programs, applications, amounts, dosages, etc.) reflects the standard of knowledge at the time of publication. Despite careful manuscript preparation and proof correction, errors can nevertheless occur. Authors, editors and publisher disclaim all responsibility for any errors or omissions or liability for the results obtained from use of the information, or parts thereof, contained in this work.

The citation of registered names, trade names, trademarks, etc. in this work does not imply, even in the absence of a specific statement, that such names are exempt from laws and regulations protecting trademarks etc. and therefore free for general use.

ISSN 1565-1339 • e-ISSN 2191-0294

All information regarding notes for contributors, subscriptions, open access, back volumes and orders is available online at www.degruyter.com/ijnsns.

\section{RESPONSIBLE EDITOR}

Prof. Björn Birnir, Department of Mathematics, University of California, Santa Barbara, CA 93106, USA,

Email: birnir@math.ucsb.edu

JOURNAL MANAGER Esther Markus, De Gruyter, Genthiner Straße 13, 10785 Berlin, Germany, Tel.: +49 (0)30 26005 - 127, Fax: +49 (0)30 26005 - 250, Email: esther.markus@ degruyter.com

RESPONSIBLE FOR ADVERTISEMENTS Heiko Schulze, De Gruyter, Genthiner Straße 13, 10785 Berlin, Germany. Tel.: +49 (0)30.260 05-358, Fax: +49 (0) 30.260 05-264 Email: anzeigen@ degruyter.com

(C) 2015 Walter de Gruyter GmbH, Berlin/Boston

TYPESETTING Integra Software Services Pvt. Ltd., Pondicherry, India

PRINTING Franz X. Stückle Druck und Verlag e. K., Ettenheim Printed in Germany

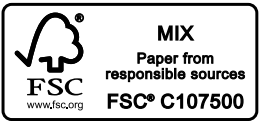




\section{Contents}

Weiyi Liu, Chaojin Fu and Boshan Chen

Stability and Hopf Bifurcation of a Predator-Prey Biological

Economic System with Nonlinear Harvesting Rate — 249

Marwan Alquran, H.M. Jaradat, Safwan Al-Shara' and Fadi Awawdeh

A New Simplified Bilinear Method for the $\boldsymbol{N}$-Soliton Solutions for a Generalized FmKdV Equation with

Time-Dependent Variable Coefficients — 259

Kolade M. Owolabi

Robust IMEX Schemes for Solving Two-Dimensional

Reaction-Diffusion Models - 271
Jing Zhu, Dan Yang, Liancun Zheng and Xinxin Zhang Second-Order Slip Effects on Heat Transfer of Nanofluid with Reynolds Model of Viscosity in a Coaxial

Cylinder -285

Nagma Irfan and A. H. Siddiqi

An Application of Wavelet Technique in Numerical

Evaluation of Hankel Transforms - 293 